\title{
Occurrence of alcohol addiction in the adult population living in rural areas
}

\author{
Bożena Mroczek ${ }^{1, A, D, F}$, Łukasz Mrozik $^{2, B}$, Artur Kotwas ${ }^{3, C, E}$, Halina Brzeźniak ${ }^{4, D}$, \\ Weronika Wolińska' ${ }^{1, D}$, Marta Niewczas ${ }^{5, B}$, Paulina Zabielska ${ }^{3, D, E}$, Anna Grzywacz ${ }^{6, A, F}$ \\ ${ }^{1}$ Department of Human Sciences in Medicine, Pomeranian Medical University, Szczecin, Poland \\ ${ }^{2}$ Agricultural Farm, Western Pomerania, Poland \\ ${ }^{3}$ Department of Social Medicine and Public Health, Chair of Social Medicine, Pomeranian Medical University, Szczecin, Poland \\ ${ }^{4}$ Independent Public Health Care Institute of Higher Education, Szczecin, Poland \\ ${ }^{5}$ Faculty of Physical Education University, Rzeszów, Poland \\ ${ }^{6}$ Independent Laboratory of Health Promotion, Pomeranian Medical University, Szczecin, Poland \\ A - Research concept and design, B - Collection and/or assembly of data, C - Data analysis and interpretation, \\ $D$ - Writing the article, E - Critical revision of the article, F-Final approval of article
}

Mroczek B, Mrozik Ł, Kotwas A, Brzeźniak H, Wolińska W, Niewczas M, Zabielska P, Grzywacz A. Occurrence of alcohol addiction in the adult population living in rural areas. Ann Agric Environ Med. 2018; 25(4): 659-664. doi: 10.26444/aaem/80796

\begin{abstract}
Introduction. Risky alcohol consumption is one of the main threats to the health of both individuals and society as a whole. These threats affect, among others, health, safety and financial situation. Their scale and intensity cause the issue of alcohol consumption to become a significant challenge for public health.

Objective. The aim of the study was assessment of the occurrence of the problem of alcohol consumption among residents of rural areas in Western Pomerania and the Lubuskie Province of Western Poland.

Materials and method. The study was conducted on 350 residents of rural areas - 236 females (66.4\%) and 114 males (32.6\%), median age - $42 \mathrm{y}$. (range - 20-76 years). The tools used included MAST and AUDIT questionnaires, Health Behaviour Inventory (HBI), Social Activity Questionnaire (SA), and original questions.

Results. In the studied group the problem with proper alcohol consumption occurred. High convergence was observed between results obtained by individual respondents with both tools $(r=0.868$ with $p<0.001)$. Median on the AUDIT scale indicated the possibility of alcoholism occurrence in the studied group, whereas the MAST test indicated the necessity to conduct an in-depth alcohol diagnosis. Factors that differentiated the points scored by respondents in AUDIT test included gender - more women drank alcohol in a risky way $(Z=-2.54, p=0.011)$, education, health behaviours, professional passivity, and using various forms of support. In the AUDIT test, the alcoholism threat was over 7 times higher in people without permanent employment (vs. employed people), OR=7.41 (95\% Cl-4.56-12.04), and in MAST test it was over 4 times higher in these individuals: $\mathrm{OR}=4.45(95 \% \mathrm{Cl}-2.64-7.49)$.

Conclusions. Results indicate the need to intensify the work of regional facilities for solving alcohol problems, as well as educational campaigns in schools and health care facilities.
\end{abstract}

Key words

MAST Test, AUDIT Test, alcohol drinking, HBI, social activity

\section{INTRODUCTION}

Strengthening rural policy has become one of the main priorities of the European Union (EU). Taking into consideration the fact that in 2016, $19.2 \%$ of the EU-28 population lived in rural areas of significant size, development of these areas, as well as the quality of life of its residents is an extremely significant part of EU policy $[1,2]$.

In comparison to other EU countries, Polish rural regions show a rather high immunity to the influence of urban areas, with a significant number of people employed in the farming industry and a relatively low percentage of people with higher education $[3,4,5]$.

Environmental determinant of risky alcohol consumption. Alcohol consumption is defined as annual sales of pure

Address for correspondence: Paulina Zabielska, Department of Social Medicine and Public Health, Chair of Social Medicine, Pomeranian Medical University in Szczecin, Żołnierska, 48, 71-210 Szczecin, Poland

E-mail: paulina.zabielska@pum.edu.pl

Received: 17.05.2017; accepted: 25.11.2017; first published: 09.01.2018 alcohol in litres per person aged 15 years and older. On average, a Polish individual older than 15 drinks 10.5 litres of pure alcohol a year [6]. Alcohol is a certain element of Polish culture and in many rural environments it is a part of specific rituals - drinking alcohol is considered tradition, and in rural areas refusal to drink alcohol may result in social ostracism $[7,8]$. A significant decisive factor for drinking alcohol by rural residents is boredom. It is estimated that in Poland $2 \%$ of the society is addicted to alcohol (ca. 800,000people), those drinking excessively - ca. 3 million, and the number of people drinking in a risky way is difficult to estimate. This problem also concerns young people. It is estimated that among teenagers aged 11-15, approximately $50 \%$ of them had contact with alcohol and were intoxicated at least twice in their life (this percentage rapidly increases with age) [9]. The highest alcohol consumption above average was recorded in the northern and south-western regions of Poland, and in the Małopolskie Region in the south-east [5].

There are more drinkers among people with higher education than among those with secondary or basic vocational education. The number of abstinents increases 
with age, in the age group up to 25 this was $6 \%$ and among people above the age of 60 - as high as $27 \%$. Alcohol is more often consumed by people in cities with more than 100,000 inhabitants, from $84 \%-87 \%$ of all residents above the age of 18 , in comparison to $82 \%$ of inhabitants of rural inhabitants. It was determined that in comparison to other EU countries, consumption of alcohol in Poland has been increasing since the year 2000. Forecasts indicate that Poland is one of the few countries in Europe where alcohol consumption will continue to increase $[6,10]$.

Alcohol is a psychoactive substance which causes addiction [11]. Alcohol consumption poses numerous threats to individuals, their families and the whole of society. These threats affect, among others, health, safety and financial situation. Their scale and intensity cause the issue of alcohol consumption to become a significant challenge for public health [10]. For this reason, alcohol addiction is diagnosed based on criteria included in ICD-10, symbol F10.2. Questionnaire methods provide means to note and initially diagnose the signs of disorders related to alcohol abuse, including risky drinking, harmful drinking and alcohol addiction [12]. Tests used in clinical diagnosis: Cut Down, Annoyed, Guilty, Eye Opener (CAGE) [13, 14], Michigan Alcoholism Screening Test (MAST) [15], and the Alcohol Use Disorders Identification Test (AUDIT), are the basis for further diagnosis of the problem and the introduction of preventive measures and treatment $[9,13,16]$.

\section{OBJECTIVE}

The aim of the study was assessment of the occurrence of the problem of alcohol consumption among residents of rural areas. It was based on the assumption that gender, lower education level and low social activity determine the occurrence of alcohol problems.

\section{MATERIALS AND METHOD}

The study was conducted in Poland in 2016 among residents of former State-Owned Farms located in Western Pomerania and Lubuskie Province of Western Poland. The Bioethics Committee of the Pomeranian Medical University in Szczecin approved the study (Decision No. KB-0012/21/16). Analysis was based on questionnaires completed by 350 respondents - including 236 women (67.62\%) and 114 men (32.38\%). Median age of respondents was 42 (range: $20-76$ years); the majority of respondents had secondary education (33.24\%, $116)$ and basic vocational education (29.23\% (102). Detailed socio-demographic data are shown in Table 1.

The study was conducted by means of direct anonymous survey. Questionnaires included MAST (Michigan Alcoholism Screening), AUDIT (Alcohol Use Disorders Identification Test), (HB (Health Behaviour Inventory I) and SA (Social Activity Questionnaire).

MAST and AUDIT test survey. Study results were analysed based on the following standards: Test (MAST) and (AUDIT) $[12,13,17]$.

MAST test consisted of 25 questions related to alcohol consumption, opinions of family and friends, issues caused by drinking and symptoms of alcohol addiction. Respondents
Table 1. Characteristics of respondents

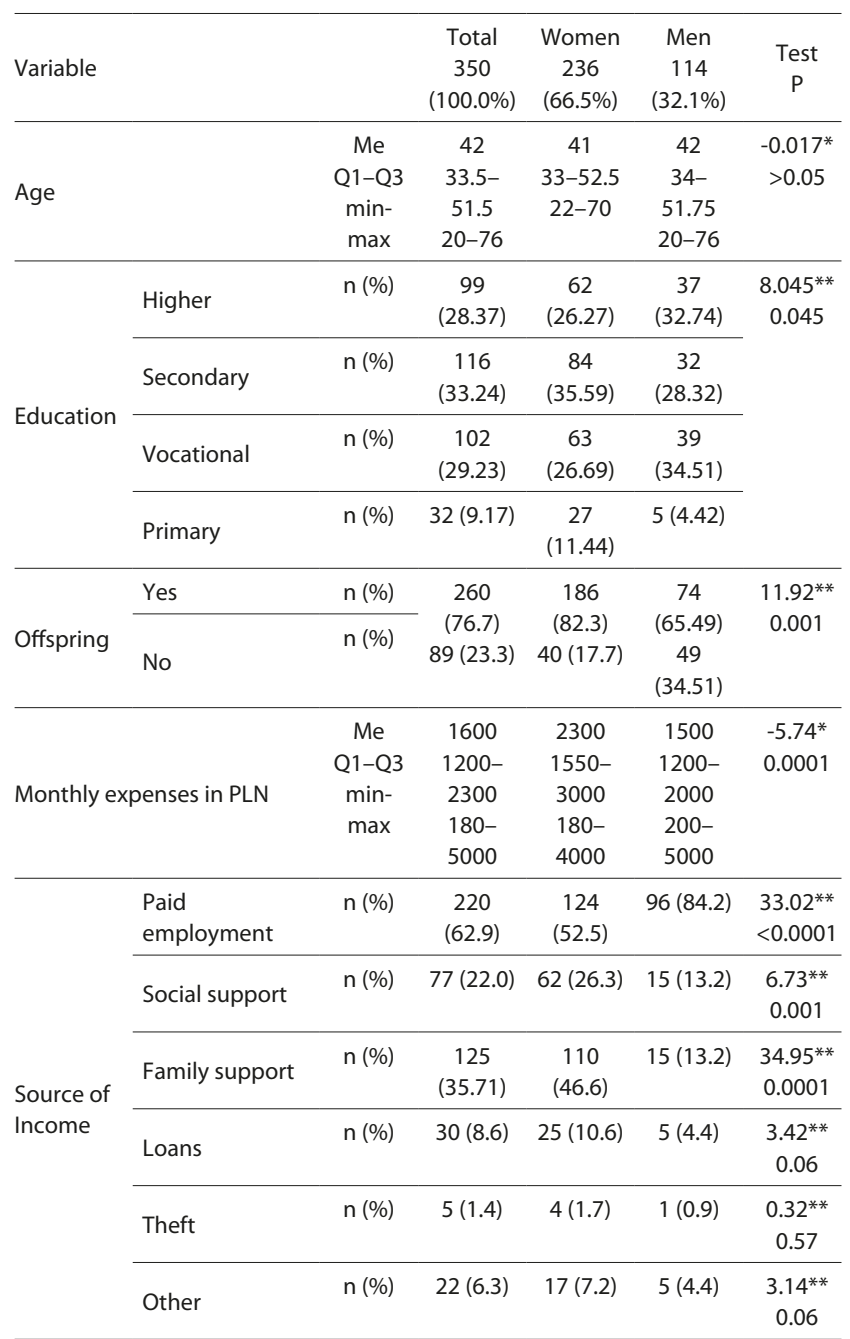

*U Mann - Whitney Test; ** Chi^2 Test; p - significance level

answered the questions with: "yes" or: "no". A score of 5 or more points indicates the probability of alcohol addiction, 4 points indicate that the survey has to be repeated. Sensitivity of studies conducted by means of this test on a US population was $98 \%[15,18]$.

The AUDIT test refers to short alcohol interventions $[16,17]$. Its aim is to identify respondents who consume alcohol in a way that is risky to their health or have already experienced negative effects of their addiction [19,20]. The test consists of 10 questions that allow the authors to assess alcohol consumption, evaluate drinking-related behaviours, and issues related to alcohol use which have occurred within a year prior to the study [21]. Test questions were defined by the following symptoms:

(a) signs of alcohol addiction (4 questions);

(b) adverse effects after alcohol use (1 question);

(c) issues caused by alcohol (2 questions);

(d) amount of alcohol consumed (3 questions) [17, 22].

Scores of 8 points or more $(\max 40)$ indicate problematic drinking and serious issues related to alcohol use [21]. In studies conducted by Seppä et al. (1995), sensitivity of the test was $100 \%$ and it was proved that AUDIT is significantly more sensitive than CAGE and MAST questionnaires, especially in determining the threat in women abusing alcohol [22]. 
The author also used the Health Behaviour Inventory (HBI) developed by Z. Juczynski. The instrument consists of 24 statements that measure 4 categories of pro-health behaviour: healthy eating habits, preventive behaviours, positive mental attitudes and health practices [23]. Patients mark the frequency related to health behaviour and the right health-related activity: 1- almost never, 2 - rarely, 3 from time to time, 4 - often, 5 - almost always. The sum of results from all 4 scales indicates the score for general health behaviour (range: 24-120), where the score correlates with the intensity of healthy behaviour (the higher the score, the higher the level of declared healthy behaviours). Obtained results were converted to a sten scale developed by the author of this tool. Results within 1-4 stens are considered a low score, values of 5 and 6 stens are considered moderate and $7-10$ stens are high results.

The intensity of health behaviour in particular categories is the sum of all answers on a particular sub-scale divided by 6 . The HBI internal consistency measured with a-Cronbach equals 0.85 [23].

The original social activity questionnaire consisted of questions about average level of monthly expenses (openended question), income sources (paid employment, social support, financial support from family, loans, criminal acts), expenses on particular goods (sustaining basic needs, psychoactive substances, fun, health), daily schedule (getting up in the morning, number of friends, time alone, time with family and friends, family talks, going out), participation in culture, social activity. Results were grouped into scales: up to 20 points - respondent does not participate in social activity at all, 21-40 pt. - rarely, 41-60 pt. - quite often, and results above 69 pt. - frequent high social activity.

Statistical Analysis. The type of distribution for all variables was determined. The Shapiro-Wilk test was employed to verify normality of these distributions. The distribution of the analyzed variables did not have normal distribution. Medians and range of variability (extremes) were calculated for measurable (quantitative) variables, while for qualitative variables, the frequency (percentage) was determined. Correlation measures were used to determine relationships between analysed variables. Ordinal and interval variables that failed to meet the normal distribution condition were analysed by means of Spearman rank-order correlation coefficient $(r)$.

The Mann-Whitney $\mathrm{U}$ is a non-parametric test and Chi2 Pearson's indepedence test was used. Logistic regression was used to define the influence of explanatory variables on the odds ratio (OR) with a 95\% confidence interval.

A test probability level of $\mathrm{p} \leq 0.05$ was considered statistically significant for all tests. Statistical analysis was conducted by means of PASW Statistics version 18 and Statistica 12.5 software.

\section{RESULTS}

Analysis of average scores obtained by respondents on both scales indicated the existence of a problem with safe alcohol use. Scores obtained by respondents in both tools have a high result convergence $(\mathrm{r}=0.868 ; \mathrm{p}<0.0001)(\mathrm{r}=0.87 ; \mathrm{p}<0.0001)$.

AUDIT test determined a group of $43.43 \%$ (152) respondents of both genders who require in-depth diagnosis for alcohol prevention. In MAST test, two-thirds of respondents - 62.86\% (220) qualified for inclusion in the alcoholism threat group. Safe alcohol use was determined in $37.14 \%$ (130) respondents.

Factors influencing alcohol-related behaviours. The factor differentiating the scores obtained on the AUDIT scale was gender $(Z=-2.54 ; p=0.011)$, female respondents showed more risky alcohol consumption than men. AUDIT scale median for women was 7 pt. vs. 3 pt. for men $(Z=-2.54$; $\mathrm{p}=0.01)$. In MAST test, it was $15.5 \mathrm{pt}$. for women and $6 \mathrm{pt}$. for men $(Z=-1.06 ; p=0.29)$. The number of points scored by respondents in MAST and AUDIT questionnaires was determined by health behaviours (HB) and social activity (SA) $(\mathrm{p}<0.05)$.

In the studied group, the average $\mathrm{HB}$ level predominated (5 stens), Q1 3 pt. - Q3 6 pt. (Tab. 2). Highest scores were given to preventive behaviours, lowest to health practices and healthy eating habits. Women showed higher levels of general $\mathrm{HB}$ than men $(\mathrm{Z}=4.14 ; \mathrm{p}=0.04)$ and in the following categories: healthy eating habits $(Z=5.55 ; \mathrm{p}=0.02)$, preventive behaviours $(\mathrm{Z}=5.02 ; \mathrm{p}=0.02)$ and positive mental attitude $(\mathrm{Z}=12.61 ; \mathrm{p}<0.001)$.

Education also had significantly differentiated levels of general health behaviours: an increase in education level resulted in an increase in the level of health behaviours $(\mathrm{r}=0.14 ; \mathrm{p}=0.01)$, in categories of healthy eating habits $(\mathrm{r}=0.16 ; \mathrm{p}=0.002)$, as well as positive mental attitude $(\mathrm{r}=0.21 ; \mathrm{p}<0.001)$.

An increase in the number of points in the tests was the result of a $0.38 \mathrm{pt}$. lower level of health behaviours (HB) in AUDIT test and 0.42 pt. in MAST test.

Table 2. Analysis of differences in HBI scores, including respondents' gender

\begin{tabular}{|c|c|c|c|c|c|c|c|}
\hline $\mathrm{HBI}$ & & Total & Stens & $\mathrm{EH}$ & PB & MA & $\mathrm{HP}$ \\
\hline \multirow{5}{*}{ Women } & Median & 78.00 & 5.00 & 3.17 & 3.50 & 3.33 & 3.00 \\
\hline & Minimum & 36.00 & 1.00 & 1.50 & 1.50 & 1.33 & 1.17 \\
\hline & Maximum & 111.00 & 9.00 & 5.00 & 5.00 & 5.00 & 4.50 \\
\hline & $\mathrm{Q}_{1}$ & 69.25 & 3.00 & 2.67 & 2.83 & 2.83 & 2.67 \\
\hline & $\mathrm{Q}_{3}$ & 88.00 & 6.00 & 3.67 & 4.00 & 3.83 & 3.50 \\
\hline \multirow{5}{*}{ Men } & Median & 78.50 & 5.50 & 2.83 & 3.33 & 3.00 & 3.00 \\
\hline & Minimum & 39.00 & 1.00 & 1.00 & 1.00 & 1.50 & 1.50 \\
\hline & Maximum & 110.00 & 10.00 & 4.67 & 5.00 & 4.67 & 4.33 \\
\hline & $\mathrm{Q}_{1}$ & 59.50 & 2.75 & 2.00 & 2.17 & 2.67 & 2.63 \\
\hline & $\mathrm{Q}_{3}$ & 80.00 & 6.00 & 3.33 & 3.54 & 3.33 & 3.38 \\
\hline \multirow{2}{*}{\multicolumn{2}{|c|}{$\begin{array}{l}\text { U Mann-Whitney } \\
\text { test; } p\end{array}$}} & 4.135 & 1.625 & 5.547 & 5.023 & 12.611 & 0.042 \\
\hline & & 0.042 & 0.202 & 0.019 & 0.025 & 0.000 & 0.837 \\
\hline
\end{tabular}

$\mathrm{HBI}$ - Health Behaviour Inventory; PB - preventive behaviour; $\mathrm{EH}$ healthy eating habits, MA - positive mental attitudes; HP - health practices; $\mathrm{p}$-significance level

Social activity. Increase in number of points in AUDIT test was also the result of a $0.52 \mathrm{pt}$. drop in social activity score related mainly to sustaining basic needs (SA), in MAST test it was $0.48 \mathrm{pt}$. 
Table 3. Analysis of differences in AUDIT and MAST scores, based on social activity

\begin{tabular}{lcccc}
\hline \multirow{2}{*}{ Variable } & \multicolumn{2}{c}{ AUDIT } & \multicolumn{2}{c}{ MAST } \\
\cline { 2 - 5 } & Chi^2 & $\mathrm{p}$ & $\mathrm{Chi} \wedge 2$ & $\mathrm{p}$ \\
\hline Social support (Social Welfare Centres) & 49.93 & 0.000 & 24.43 & 0.000 \\
\hline Offspring & 2.94 & 0.09 & 0.02 & 0.90 \\
\hline Paid employment & 72.17 & 0.000 & 34.24 & 0.000 \\
\hline Financial support from social institutions & 25.96 & 0.000 & 17.51 & 0.000 \\
\hline Financial support from family & 50.72 & 0.000 & 23.19 & 0.000 \\
\hline Loans & 9.65 & 0.002 & 7.79 & 0.005 \\
\hline Theft & 0.04 & 0.84 & 1.29 & 0.26 \\
\hline Pension & 1.12 & 0.29 & 2.56 & 0.11 \\
\hline Work ability & 0.91 & 0.63 & 1.42 & 0.49 \\
\hline Marital status & 6.00 & 0.04 & 15.108 & 0.000 \\
\hline
\end{tabular}

Chi^2 Test; $p$-significance level

Based on differences analysis, statistical significance for the threat of risky alcohol consumption was confirmed in the AUDIT test for respondents who were:

- unemployed ( $72.7 \%$ vs. $26.5 \%)$;

- receiving financial support from social support institutions (67.4\% vs. $29.1 \%)$;

- receiving financial support from various social institutions (70.1\% vs. $37.4 \%)$;

- receiving financial support from family (69.5\% vs. $30.1 \%)$;

- taking loans (71.0\% vs. $41.9 \%)$;

- single (73.4\% vs. $53.1 \%$ ) (Tab. 3).

Based on the MAST test, the group of people at risk of alcoholism includes respondents who were:

- receiving social support (79.3\% vs. $53.2 \%)$;

- unemployed (82.6\% vs. $51.6 \%)$;

- receiving financial support from social support institutions (84.4\% vs. $58.5 \%)$;

- receiving financial support from family (80.5\% vs. $54.8 \%)$;

- taking loans (87.1\% vs. $61.9 \%)$;

- single (70.1\% vs. $37.4 \%)$.

Odds ratios. Odds of having a high level of health behaviours was twice as high in respondents with secondary and higher education than in people with primary education $(\mathrm{OR}=1.90$, $95 \%$ CI $-1.2-2.9 ; \mathrm{p}=0.004$. Odds of achieving a high score in AUDIT test, indicating the threat of alcoholism, were more than 7 times higher in unemployed respondents (vs. employed), OR - 7.41 (95\% CI - 4.56 - 12.04; p<0.0001). Similarly, in MAST test, these odds were more than 4 times higher in unemployed respondents (vs. employed): OR -4.45 (95\% CI - $2.64-7.49$; $\mathrm{p}<0.0001)$.

Risk of score increase in AUDIT and MAST tests was lower in respondents who did not receive financial support from social support institutions or family $(\mathrm{p}<0.0001)$.

\section{DISCUSSION}

The health condition of people can be assessed on the basis of numerous data being collected in the EU and analysed with the same methodology. A study worth emphasising is the European Union Statistics on Income and Living Conditions (EU-SILC), coordinated by the European Statistical Office, as well as the European Health Interview Survey (EHIS) [24], as well as studies conducted by the Central Statistical Office of Poland (GUS), which complement Eurostat studies even though the results differ from those of EU-SILC and EHIS $[25,26,27]$.

Health behaviours indicate health attitudes [23] and belong to the group of basic variables analysed in Eurostat studies. Data from 2005-2012 indicate that in comparison to other EU countries, Poland has a rather weak position in terms of perception of the health condition of its citizens [24]. For this reason, the presented study was undertaken to assess health behaviours related to alcohol use among residents of villages located on former State-Owned Farm areas. The inhabitants of these villages had average health behaviours, and differentiating factors included gender and higher level of education. In the group of males, there were higher moderate values (78.5), but women had higher levels of health behaviours on individual scales. Overall, the result for men in the current study was similar to the results for men in studies conducted by Juczyński [23]. While the overall score for women was lower than men (78.0), in 3 categories of health behaviours women had higher scores. Women gave the highest ratings to eating habits, preventive practices and positive mental attitudes. The obtained results for health behaviour were similar to the assessment of health behaviours in other social groups. In a study conducted by Arendt et al. [28] on a group of 204 men aged 40-82, of whom more than half were villagers $(53 \%, 108)$, analysis showed that health behaviours of men aged over 40 were on a moderate level (5-6 stens).

Differentiating factors for health behaviours in particular categories included age above 50, place of residence and professional activity. Men from rural areas obtained lower scores on all health behaviour scales than men living in cities, except in the preventive practices category. Based on author's own research as well as studies conducted by Arendt et al., it can be stated that health behaviours are also differentiated by place of residence.

According to Arendt et al., retirement or pension had a positive impact on the level of health behaviour [28], which differs from the results from the presented study. Low levels of health behaviours were observed in men who were professionally not active, regardless of age. Additionally, it was established that a higher education level resulted in better general health behaviours. Arendt et al., however, obtained different results in which the highest score was obtained by men with vocational training. In the group of men with higher education, the highest score was obtained only in the positive mental attitude category.

Interesting results were obtained by Kurpas et al. (2014) whose objective was to describe differences in health behaviours among rural and urban inhabitants suffering from chronic illnesses. Differences in factors with a potential impact on lower levels of health behaviours included, among others, gender, age, having a partner, and the number of chronic conditions [29].

The health behaviours group includes behaviours related to alcohol consumption. In the presented study, based on AUDIT test results, more frequent risky alcohol use occurred in women in rural areas. These results are disturbing from the social standpoint, with social stigmatisation and rejection being experienced by individuals with alcohol addiction [8]. The reasons for the increasing alcohol consumption by 
women remain unclear, but hypothetical explanations can be postulated. The first is that men often do not admit that they have risky drinking habit; another explanation may be the fact that in the group of men who participated in the study were those who had moved to the countryside, but had kept in touch with the city where the drinking culture is slightly different. Besides, with the employed men working very hard, the women may experience loneliness, which could also be the reason for an increased consumption of alcohol.

More than half of all respondents (56.6\%) obtained normal scores on the AUDIT scale, which indicated a lack of alcohol problems. The rural residents who drank alcohol in a safe way were usually men, but also people with a higher education and were occupationally active. According to analysis of the MAST test results, two-thirds of the respondents qualified for inclusion in the group with an alcohol problem.

Individuals using social support from family welfare centres constituted a higher percentage of respondents with results indicating alcohol problems in both tests. Similarly, financial support from the family and taking out loans were factors increasing the frequency of results indicating risky alcohol consumption. Such results were obtained from both AUDIT and MAST tests.

Rubinsky et al. assessed the risk of alcohol addiction with tests for screenings. The objective of their study was to assess whether the results of the popular AUDIT and AUDIT-C tests could help identify patients with alcohol addiction. A reliable evaluation of their actual condition would thus enable a plan of intervention. The results obtained confirmed that these tests allowed assessment of the probability of the occurrence of alcohol addiction, and also indicate the need to make clinical decisions [30].

Selzer (1971), on the basis of results obtained from analysis of MAST tests conducted among drivers who had temporarily lost their driving licence due to drink-driving offences, concluded that there should be a very careful interpretation of MAST test results [15]; a similar conclusion regarding the MAST questionnaire was formulated by Saunders and Kershawa [31]. For this reason, 2 screening tests were used in the presented study which has shown differences in AUDIT and MAST test results in terms of qualifying respondents into groups of normal and increased alcohol consumption. Results above average were more often obtained by respondents in the MAST test. In the current study, differences were observed in qualifying respondents into groups of risky alcohol use and safe alcohol use on the basis of AUDIT and MAST tests. More results above the norm that indicate risky drinking and require in-depth diagnosis were obtained by respondents in the MAST test than in AUDIT test.

Another interesting result is the relationship between scores for general health behaviours and low amount of points in AUDIT and MAST tests. The lower the score of respondents in AUDIT and MAST tests, the higher their level of general health behaviours and social activity.

Taracha et al. [32] used the AUDIT test to screen soldiers for alcohol abuse. The screening showed that $53 \%$ of the soldiers undergoing basic military training scored at least 8 points, which was sufficient indication that in-depth clinical diagnosis was necessary. Taking into consideration the possibility that the majority of these soldiers will be cleared of suspicion of harmful drinking or addiction, this group still requires intervention as risky users potentially exposed in the future to damage to their health. In the presented study, the average values and median values were lower than in the results obtained by Taracha et al., which means that the evaluated group showed a lower level of harmful health behaviours related to alcohol consumption.

\section{CONCLUSIONS}

Risky alcohol use was confirmed more often in women, people with lower education, those receiving social support, family support and taking loans. The obtained results validate the statement that the probability of alcohol addiction exists in rural inhabitants, particularly in the group of women showing signs of alcohol abuse. The results obtained indicate the necessity to conduct in-depth alcohol diagnosis among residents of rural areas, with particular emphasis on the female group, and the lifestyle of men concerning a low level of general health behaviours.

These results are recommended to GPs, local authorities and health care officials because they confirm the need to take particular interest in the lifestyle of men and women, the inhabitants of rural areas, and involves the low level of health behaviours, with particular emphasis on behaviours related to alcohol use.

The work of local institutions in solving alcohol problems, as well as educational actions in schools and health care facilities, need to be intensified because the development of positive health behaviours is one of the main tasks of health promotion.

Further studies are required to identify factors which may have impact on the increase in harmful health behaviours and alcohol consumption. It is necessary to develop interventions and screening tests in order to prepare an efficient health promotion program for rural areas [33].

Limitations of the study. The study shows a number of limitations which need to be considered when interpreting the results and formulating conclusions. Self-descriptive standardised questionnaires were used in the study that allowed the authors to assess alcohol consumption in categories - safe drinking / risky drinking. For this reason, no unequivocal conclusions were formulated, but on the basis of obtained results, directions for further preventive and therapeutic measures were indicated. Another limitation concerns the size of the study sample, which did not allow the authors to formulate more general conclusions. However, the results of this study do indicate the necessity to conduct further studies among the inhabitants of rural areas, especially those located on former State-Owned Farms.

\section{REFERENCES}

1. Murawska A. Zmiany w poziomie jakości życia ludności na obszarach wiejskich w Polsce. J Agribus Rural Dev. 2012; 3(25): 169-180.

2. Rural Development in the EU. Statistical and Economic Information. Report 2016 https://ec.europa.eu/agriculture/sites/agriculture/files/ cap-indicators/context/2016/c1_en.pdf (access: 2017.04.04).

3. ESPON. Scientific dialogue on cities, rural areas and rising energy prices. Luxembourg, 2013.

4. Halamska M. Transformacja wsi 1989-2009: Zmienny rytm modernizacji. Studia Regionalne i Lokalne. 2011; 2(44): 5-25.

5. Główny Urząd Statystyczny. Bank Danych Lokalnych http://stat.gov. pl/obszary-tematyczne/roczniki-statystyczne/roczniki-statystyczne/ maly-rocznik-statystyczny-polski-2016,1,17.html (access: 2016.11.19). 
6. OECD. Alcohol consumption https://data.oecd.org/healthrisk/alcoholconsumption.html (access: 2017.01.23).

7. Jakubczyk A, Michalska A, Szejko N, Wojnar M. Stosunek lekarzy rodzinnych do interwencji związanych z używaniem alkoholu - polskie wyniki międzynarodowego projektu badawczego ODHIN. AiN. 2015; 28(2): 91-102.

8. Wieczorek Ł. Stygmatyzacja osób uzależnionych od alkoholu oraz systemu leczenia uzależnień w Warszawie i w społeczności lokalnej. AiN. 2015; 28(2): 103-117.

9. Kabata B. Difficulties in treatment of alcohol dependence in general practice in rural areas. Hyg Pub Health. 2011; 46(3): 385-389.

10. Zgliczyński WS. Alkohol w Polsce. INFOS. BAS - Biuro Analiz Sejmowych. 2016; 11(215): 1-4.

11. Morse R, Flavin D. The definition of alcoholism. JAMA 1992; 268(8): $1035-1039$.

12. Waszkiewicz N, Szulc A. Diagnoza nadużywania alkoholu. Przegl Lek. 2009; 66(9): 529-534.

13. Kroch S, Radomska M, Krzyżanowska-Kierepka E, Szkolnicka B, Kamenczak A, Rakus A. Rozpoznanie uzależnienia alkoholowego przy pomocy kwestionariuszy CAGE i SAAST w wybranych populacjach terapeutycznych. Przegl Lek. 2001; 58: 263-266.

14. Morawski J, Świątkiewicz G. Polska wersja testu uzależnienia od alkoholu CAGE. Probl. Alk. 1985; 35: 9-18.

15. Selzer ML. The Michigan alcoholism screening test: the quest for a new diagnostic instrument. Am J Psychiatry. 1971; 127: 1653-1658.

16. Babor TF, Grant M. From clinical research to secondary preventioninternational collaboration in the development of the Alcohol Use Disorders Identification Test (AUDIT). Alcohol Health Res World. 1989; 13(4): 371-374.

17. Babor TF, de la Fuente JR, Saunders J, Grant M. AUDIT: The Alcohol Use Disorders Identification Test. Guidelines for use in primary health care. Geneva: World Health Organization, 1992.

18. Pokorny AD, Miller BA, Kaplan HB. The brief MAST: a shortened version of the Michigan Alcoholism Screening Test. Am J Psychiatry. 1972; 129(3): 342-345.

19. Anderson P. Evaluation and monitoring of action on alcohol. WHO, Regional Publications. European Series. 1991; 32: 110-111.

20. Saunders JB, Aasland OG, Babor TF, De La Fuente JR, Grant M. Development of the Alcohol Use Disorders Identification Test (AUDIT): WHO collaborative project on early detection of persons with harmful alcohol consumption, II. Addiction. 1993; 88: 791-804.
21. Maisto SA, Krenek M. Historia używania i aktualne używanie substancji psychoaktywnych. In: Miller P. Terapia uzależnień. Metody oparte na dowodach naukowych. Warszawa: Wydaw. UW; 2013. p. 63-91.

22. Seppä K, Mäkelä R, Sillanaukee P. Effectiveness of the Alcohol Use Disorders Identification Test in Occupational Health Screenings. Alcohol Clin Exp Res. 1995; 19: 999-1003.

23. Juczyński Z. Narzędzia pomiaru w promocji i psychologii zdrowia. Warszawa: Pracownia Testów Psychologicznych. 2009.

24. Eurostat. European Statistical Office http://ec.europa.eu/eurostat/web/ main/home (access: 2016.09.23).

25. Rocznik Statystyczny 2013. Warszawa: GUS www.stat.gov.pl (access: 2017.02.28).

26. Rocznik Statystyczny Województwa Zachodniopomorskiego 2014. Szczecin: Urząd Statystyczny w Szczecinie http://szczecin.stat.gov. pl/publikacje-i-foldery/roczniki-statystyczne/rocznik-statystycznywojewodztwa-zachodniopomorskiego-2014,6,14.html (access: 2017.02.28)

27. Rocznik Statystyczny Województwa Lubuskiego 2014. Zielona Góra: Urząd Statystyczny w Zielonej Górze http://zielonagora.stat.gov.pl/ publikacje-i-foldery/roczniki-statystyczne/rocznik-statystycznywojewodztwa-lubuskiego-2014,4,9.html (access: 2017.02.28)

28. Arendt A, Laszczyńska M, Bażydło M, Kotwas A, Karakiewicz B. Estimation of health behawior in men aged over 40 years. Probl Hig Epidemiol. 2014; 95(3): 659-666.

29. Kurpas D, Mroczek B, Bielska D. Rural and urban disparities in quality of life and health-related behaviors among chronically ill patients. Rural Remote Health (Internet). 2014; 14: 2485 http://www.rrh.org.au/articles/ subviewnew.asp?ArticleID=2485 (access: 2017.01.19).

30. Rubinsky AD, Kivlahan DR, Volk RJ, Maynard Ch, Bradley KA. Estimating risk of alcohol dependence using alcohol screening scores. Drug Alcohol Depen. 2010; 108: 29-36.

31. Saunders WM, Kershaw PW. Screening tests for alcoholism - findings from a community study. Br J Addict. 1980; 75: 37-41.

32. Taracha E, Habrat B, Smela J, Gruszczyński W. Badania przesiewowe żołnierzy Zasadniczej Służby Wojskowej w kierunku nadużywania alkoholu. Próba zastosowania oznaczania aktywności heksozoaminidazy w moczu jako markera przewlekłego picia alkoholu. Alkohol Narkom. 2002; 15(l): 83-94.

33. Trinks A, Festin K, Bendtsen P, Nilsen P. Reach and effectiveness of a computer-based alcohol intervention in a Swedish emergency room. Int Emerg Nurs. 2010; 18: 138-146. 